\title{
Viral haemorrhagic fever in children
}

\author{
Nathalie E MacDermott, ${ }^{1}$ Surjo De, ${ }^{2}$ Jethro A Herberg ${ }^{1}$
}

${ }^{1}$ Section of Paediatrics, Imperial College London, London, UK

${ }^{2}$ Imported Fever Service, Public Health England, Porton Down, Wiltshire, UK

\section{Correspondence to} Dr Jethro A Herberg, Section of Paediatrics, Imperial College London, Norfolk Place, London W2 1PG, UK; j. herberg@imperial.ac.uk

Received 4 August 2015 Revised 15 December 2015 Accepted 19 December 2015

Published Online First

19 January 2016
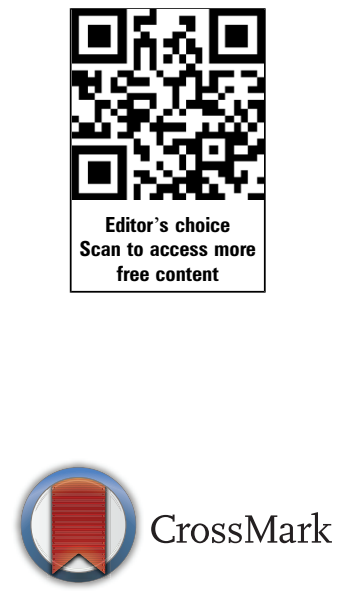

To cite: MacDermott NE, De S, Herberg JA. Arch Dis Child 2016;101:461-468.
ABSTRACT

Viral haemorrhagic fevers (VHFs) are currently at the forefront of the world's attention due to the recent Zaire ebolavirus epidemic in West Africa. This epidemic has highlighted the frailty of the world's public health response mechanisms and demonstrated the potential risks to nations around the world of imported cases of epidemic diseases. While imported cases in children are less likely, the potential for such a scenario remains. It is therefore essential that paediatricians are aware of and prepared for potential imported cases of tropical diseases, VHFs being of particular importance due to their propensity to cause nosocomial spread. Examining the four families of viruses-Filoviridae, Arenaviridae, Bunyaviridae and Flaviviridae, we describe the different types of VHFs, with emphasis on differentiation from other diseases through detailed history-taking, their presentation and management from a paediatric perspective.

The 2014-2015 Ebola virus disease (EVD) outbreak has been the largest epidemic of a filoviral haemorrhagic fever (VHF) on record. ${ }^{1}$ It threatened the stability of three West African nations and, several months into the epidemic, the potential implications of imported cases led to urgent contingency planning worldwide. As of November 2015, there had been 27 imported cases. This epidemic has highlighted the global vulnerability of an increasingly interconnected world to public health threats, and the requirement for all nations to maintain readiness for future imported cases of highly pathogenic, transmissible diseases.

Approximately $20 \%$ of EVD cases in the current epidemic were children under the age of 15 years, ${ }^{2}$ emphasising the need for vigilance for imported childhood cases. While Ebola has dominated the headlines for many months and the Zaire ebolavirus is one of the more lethal species of VHF viruses, ${ }^{3}$ healthcare professionals should be aware of several other VHF diseases, as early management in a controlled and safe healthcare environment improves survival of patients, protects healthcare workers and reduces potential for community spread.

\section{PATHOGENS CAUSING VHF IN CHILDREN}

Pathogens causing VHF encompass a broad spectrum of viruses causing a severe multisystem syndrome with vascular dysregulation and damage, which may result in overt haemorrhage. ${ }^{3}$ The viruses most commonly classified as causing VHF are listed in table $1,{ }^{3-24}$ and include species from four families (Arenaviridae, Filoviridae, Bunyaviridae and Flaviviridae). This article will focus on those classified as hazard group 4 pathogens by the UK Advisory Committee on Dangerous
Pathogens (ACDP), owing to their potential for spread within the healthcare setting and their significant public health implications. These are pathogens that, for the safety of healthcare workers and the general public, are the most important to be recognised.

\section{CLINICAL PRESENTATION OF VHF IN CHILDREN}

VHF diseases are caused by several unrelated viruses, and they cause a range of clinical symptoms. The best characterised paediatric data are for EVD (table 2). ${ }^{2-4} 25$ Each VHF virus is associated with a stronger likelihood of particular clusters of symptoms, emphasised in table 1 , but any feature can occur with any VHF virus. Percentage figures shown in table 2 reflect the occurrence of these symptoms in children under 15 years of age during the current Ebola virus epidemic in West Africa. ${ }^{2}$ Percentage figures for symptom incidence in children with non-Ebola VHFs are largely unavailable and where available are limited by small sample sizes.

The broad, non-specific nature of most symptoms makes careful travel and epidemiological history-taking essential for prompt recognition. Key questions to include in the history are shown in box $1,{ }^{20}$ some of which are location-specific. Boxes 2 and 3 give case history examples emphasising the broad nature of presentations of VHF. Clinicians must bear in mind the potential for other non-VHF, but potentially life-threatening, diseases that may present with haemorrhagic symptoms, and should consider these within the differential diagnosis and arrange appropriate investigation when investigating any suspected cases of VHF.

\section{FILOVIRIDAE}

Ebola virus disease

Ebola viruses are a genus in the filovirus family. They were first identified during an outbreak of haemorrhagic fever in the Democratic Republic of Congo (DRC, then Zaire) in 1976, and have subsequently been responsible for approximately 21 further epidemics of haemorrhagic fever affecting humans in DRC, Uganda, Sudan and Gabon. ${ }^{3}$ The most devastating epidemic to date is the recent epidemic centred in Guinea, Liberia and Sierra Leone, which has affected over 28000 people with more than 11000 deaths. ${ }^{26}$ See figure 1 for regions of the world known to be at risk from Ebola viruses.

Zaire, Sudan and Bundibugyo ebolaviruses are responsible for all human epidemics. Zaire ebolavirus causes the most lethal disease, with mortality rates of 40-90\%, while Sudan and Bundibugyo ebolaviruses have mortality rates of approximately $40-70 \%$ and $25-50 \%$, respectively. ${ }^{3}$ It remains unclear how Ebola viruses enter human transmission, although fruit bats may act as a reservoir for 
Table 1 Features of the viral haemorrhagic fevers ${ }^{3-24}$

\begin{tabular}{|c|c|c|c|c|c|c|c|}
\hline Virus & Disease & Geography & Human infection source & $\begin{array}{l}\text { Incubation } \\
\text { (days) }\end{array}$ & Treatment & Clinical precautions & $\begin{array}{l}\text { Common clinical features and case } \\
\text { fatality rate }\end{array}$ \\
\hline \multicolumn{8}{|c|}{ Family: Filoviridae; Genera: Ebolavirus ${ }^{1}$, Marburgvirus ${ }^{2}$} \\
\hline $\begin{array}{l}\text { Zaire ebolavirus, Sudan } \\
\text { ebolavirus, Bundibugyo } \\
\text { ebolavirus, Tai Forest } \\
\text { ebolavirus }^{1}\end{array}$ & Ebola virus disease & $\begin{array}{l}\text { Africa (central, western } \\
\text { and eastern) }\end{array}$ & $\begin{array}{l}\text { Fruit bats, infected } \\
\text { non-human primates, } \\
\text { human-to-human, nosocomial, } \\
\text { sexual transmission }\end{array}$ & $2-21$ & $\begin{array}{l}\text { Supportive and } \\
\text { antibody based } \\
\text { therapies }\end{array}$ & $\begin{array}{l}\text { Isolation of patient } \\
\text { Full PPE for healthcare workers }\end{array}$ & $\begin{array}{l}\text { Fever, weakness, headache, profuse } \\
\text { diarrhoea, vomiting, conjunctival injection, } \\
\text { hiccoughs, haemorrhage } \\
\text { CFR }=25-90 \%\end{array}$ \\
\hline Marburg marburgvirus ${ }^{2}$ & Marburg HF & $\begin{array}{l}\text { Africa (central, eastern } \\
\text { and southern) }\end{array}$ & $\begin{array}{l}\text { Fruit bats, infected } \\
\text { non-human primates and } \\
\text { forest antelope, } \\
\text { human-to-human, nosocomial }\end{array}$ & $2-21$ & Supportive & $\begin{array}{l}\text { Isolation of patient } \\
\text { Full PPE for healthcare workers }\end{array}$ & $\begin{array}{l}\text { Fever, weakness, headache, myalgia, } \\
\text { vomiting, diarrhoea, conjunctival injection, } \\
\text { haemorrhage } \\
\text { CFR=24-88\% }\end{array}$ \\
\hline \multicolumn{8}{|c|}{ Family: Arenaviridae; Genus: Mammarenavirus } \\
\hline Lassa mammarenavirus & Lassa fever & West and central Africa & $\begin{array}{l}\text { Rodents, human-to-human, } \\
\text { nosocomial, sexual } \\
\text { transmission }\end{array}$ & $6-21$ & $\begin{array}{l}\text { Supportive and } \\
\text { ribavirin }\end{array}$ & $\begin{array}{l}\text { Isolation of patient } \\
\text { Full PPE for healthcare workers }\end{array}$ & $\begin{array}{l}\text { Fever, sore throat, retrosternal pain, } \\
\text { myalgia, severe cases—gross oedema, } \\
\text { haemorrhage, deafness } \\
\text { CFR=Approximately } 15 \% \text { (hospitalised } \\
\text { patients) }\end{array}$ \\
\hline Junin mammarenavirus & Argentine HF & Argentina & $\begin{array}{l}\text { Rodents, human-to-human, } \\
\text { nosocomial }\end{array}$ & 5-19 & $\begin{array}{l}\text { Supportive and } \\
\text { convalescent } \\
\text { plasma }\end{array}$ & $\begin{array}{l}\text { Isolation of patient } \\
\text { Full PPE for healthcare workers }\end{array}$ & $\begin{array}{l}\text { Fever, headache, myalgia, vomiting, } \\
\text { retro-orbital pain, haemorrhage, irritability, } \\
\text { ataxia } \\
\text { CFR=up to } 30 \%\end{array}$ \\
\hline Machupo mammarenavirus & Bolivian HF & Bolivia & $\begin{array}{l}\text { Rodents, human-to-human } \\
\text { (rare), nosocomial (rare) }\end{array}$ & 5-19 & $\begin{array}{l}\text { Supportive and ? } \\
\text { ribavirin }\end{array}$ & $\begin{array}{l}\text { Isolation of patient } \\
\text { Full PPE for healthcare workers }\end{array}$ & $\begin{array}{l}\text { Fever, headache, myalgia, vomiting, } \\
\text { retro-orbital pain, haemorrhage, irritability, } \\
\text { ataxia } \\
\text { CFR=up to } 30 \%\end{array}$ \\
\hline Guanarito mammarenavirus & Venezuelan $\mathrm{HF}$ & Venezuela & $\begin{array}{l}\text { Rodents, human-to-human, } \\
\text { nosocomial }\end{array}$ & $? 7-14$ & $\begin{array}{l}\text { Supportive and? } \\
\text { ribavirin }\end{array}$ & $\begin{array}{l}\text { Isolation of patient } \\
\text { Full PPE for healthcare workers }\end{array}$ & $\begin{array}{l}\text { Fever, headache, sore throat, arthralgia/ } \\
\text { myalgia, diarrhoea, conjunctivitis, } \\
\text { haemorrhage } \\
\text { CFR=up to } 30 \%\end{array}$ \\
\hline Sabia mammarenavirus & Brazilian HF & Brazil & $\begin{array}{l}\text { Rodents, human-to-human, } \\
\text { nosocomial }\end{array}$ & $? 7-14$ & $\begin{array}{l}\text { Supportive and } \\
\text { ribavirin }\end{array}$ & $\begin{array}{l}\text { Isolation of patient } \\
\text { Full PPE for healthcare workers }\end{array}$ & $\begin{array}{l}\text { Fever, headache, myalgia, vomiting, } \\
\text { retro-orbital pain, haemorrhage, jaundice, } \\
\text { hepatic necrosis } \\
\text { CFR=up to } 30 \%\end{array}$ \\
\hline Chapare mammarenavirus & Chapare HF & Bolivia & $\begin{array}{l}\text { Rodents, human-to-human, } \\
\text { nosocomial }\end{array}$ & $? 7-14$ & $\begin{array}{l}\text { Supportive and } \\
\text { ribavirin }\end{array}$ & $\begin{array}{l}\text { Isolation of patient } \\
\text { Full PPE for healthcare workers }\end{array}$ & $\begin{array}{l}\text { Unclear, little known, similar clinical } \\
\text { presentation to Bolivian HF }\end{array}$ \\
\hline Lujo mammarenavirus & Lujo & Zambia & $\begin{array}{l}\text { Rodents, human-to-human, } \\
\text { nosocomial }\end{array}$ & $9-13$ & $\begin{array}{l}\text { Supportive and } \\
\text { ribavirin }\end{array}$ & $\begin{array}{l}\text { Isolation of patient } \\
\text { Full PPE for healthcare workers }\end{array}$ & $\begin{array}{l}\text { Fever, myalgia, sore throat, headache, } \\
\text { diarrhoea, vomiting, rash, facial oedema, } \\
\text { conjunctival injection, haemorrhage } \\
\text { CFR=approx. } 80 \%\end{array}$ \\
\hline \multicolumn{8}{|c|}{ Family: Bunyaviridae; Genera: Nairovirus' ${ }^{1}$, Phlebovirus ${ }^{2}$, Hantavirus ${ }^{3}$} \\
\hline $\begin{array}{l}\text { Crimean-Congo hemorrhagic } \\
\text { fever virus }^{1}\end{array}$ & Crimean-Congo HF & $\begin{array}{l}\text { Africa, Balkans, Russia, } \\
\text { Middle East, central } \\
\text { Asia, western China }\end{array}$ & $\begin{array}{l}\text { Ticks, livestock animals (cattle, } \\
\text { sheep, goats), ostriches, } \\
\text { human-to-human, nosocomial }\end{array}$ & $1-13$ & $\begin{array}{l}\text { Supportive and } \\
\text { ribavirin }\end{array}$ & $\begin{array}{l}\text { Isolation of patient } \\
\text { Full PPE for healthcare workers }\end{array}$ & $\begin{array}{l}\text { Fever, myalgia, headache, vomiting, } \\
\text { diarrhoea, bleeding (nose, gums) } \\
\text { CFR }=30 \%(15-70 \%) \text {, approximately } 5 \% \text { in } \\
\text { children }<18 \text { years }\end{array}$ \\
\hline
\end{tabular}




\section{Table 1 Continued}

\begin{tabular}{|c|c|c|c|c|c|c|c|}
\hline Virus & Disease & Geography & Human infection source & $\begin{array}{l}\text { Incubation } \\
\text { (days) }\end{array}$ & Treatment & Clinical precautions & $\begin{array}{l}\text { Common clinical features and case } \\
\text { fatality rate }\end{array}$ \\
\hline $\begin{array}{l}\text { Severe fever with } \\
\text { thrombocytopenia syndrome }_{\text {virus }^{2}}\end{array}$ & $\begin{array}{l}\text { Severe fever with } \\
\text { thrombocytopenia } \\
\text { syndrome }\end{array}$ & $\begin{array}{l}\text { China, Japan, South } \\
\text { Korea and North Korea }\end{array}$ & $\begin{array}{l}\text { Ticks, human-to-human, } \\
\text { nosocomial }\end{array}$ & $5-15$ & Supportive & $\begin{array}{l}\text { Isolation of patient } \\
\text { Full PPE for healthcare workers }\end{array}$ & $\begin{array}{l}\text { Fever, thrombocytopenia, leucopenia, } \\
\text { myalgia, vomiting, diarrhoea, headache with } \\
\text { evolving disseminated intravascular } \\
\text { coagulation, haemorrhage and multiorgan } \\
\text { failure. } \\
\text { CFR }=8 \%\end{array}$ \\
\hline Rift Valley fever virus $^{2}$ & Rift Valley fever & $\begin{array}{l}\text { Sub-Saharan and } \\
\text { northern Africa, Saudi } \\
\text { Arabia, Yemen }\end{array}$ & $\begin{array}{l}\text { Livestock animals, } \\
\text { unpasteurised milk, Aedes } \\
\text { mosquitoes, haematophagous } \\
\text { flies }\end{array}$ & $2-6$ & $\begin{array}{l}\text { Supportive and } \\
\text { ribavirin and } \\
\text { antibody therapies }\end{array}$ & $\begin{array}{l}\text { No interhuman transmission- } \\
\text { Standard IP\&C measures }\end{array}$ & $\begin{array}{l}\text { Fever, myalgia/arthralgia, headache, } \\
\text { photophobia } \\
\text { CFR } \leq 1 \% \text { (approximately } 50 \% \text { in } \\
\text { haemorrhagic form) }\end{array}$ \\
\hline $\begin{array}{l}\text { Hantaan virus, Seoul virus, } \\
\text { Puumala virus }{ }^{3}\end{array}$ & $\begin{array}{l}\text { Haemorrhagic fever } \\
\text { with renal syndrome }\end{array}$ & worldwide & Rodents & $9-35$ & $\begin{array}{l}\text { Supportive and } \\
\text { ribavirin }\end{array}$ & $\begin{array}{l}\text { No documented interhuman } \\
\text { transmission—standard IP\&C } \\
\text { measures }\end{array}$ & $\begin{array}{l}\text { Fever, headache, blurred vision, myalgia, } \\
\text { vomiting, proteinuria, renal impairment, } \\
\text { mild haemorrhage. Hantaan CFR }=5-15 \% \\
\text { Puumala CFR } \leq 1 \%\end{array}$ \\
\hline $\begin{array}{l}\text { Sin Nombre virus, Black } \\
\text { Creek Canal virus, Bayou } \\
\text { virus, Andes virus }\end{array}$ & $\begin{array}{l}\text { Hantavirus pulmonary } \\
\text { syndrome }\end{array}$ & Americas & Rodents & $7-28$ & Supportive & $\begin{array}{l}\text { Occasional interhuman spread } \\
\text { for Andesvirus-isolation of } \\
\text { patient and full PPE. Standard } \\
\text { IP\&C measures for other } \\
\text { Hantaviruses }\end{array}$ & $\begin{array}{l}\text { Fever, myalgia, headache, vomiting, } \\
\text { diarrhoea, shortness of breath, cough, } \\
\text { pulmonary oedema, pleural effusion } \\
\text { CFR }=40-50 \%\end{array}$ \\
\hline \multicolumn{8}{|c|}{ Family: Flaviviridae Genus: Flavivirus } \\
\hline Dengue virus (types 1-4) & $\begin{array}{l}\text { Dengue HF, Dengue } \\
\text { shock syndrome }\end{array}$ & $\begin{array}{l}\text { Africa, South-East Asia, } \\
\text { West Pacific Americas, } \\
\text { East Mediterranean } \\
\text { region }\end{array}$ & Aedes mosquitoes & $4-10$ & Supportive & $\begin{array}{l}\text { No interhuman transmission- } \\
\text { occasional nosocomial } \\
\text { transmission from needlestick } \\
\text { injuries-Standard IP\&C } \\
\text { measures }\end{array}$ & $\begin{array}{l}\text { Fever, myalgia, headache, rash, } \\
\text { haemorrhage } \\
\text { CFR } \leq 1 \% \text { (up to } 10 \% \text { for severe } \\
\text { (haemorrhagic) Dengue) }\end{array}$ \\
\hline Yellow fever virus & Yellow fever & Africa, South America & Aedes mosquitoes & $3-6$ & Supportive & $\begin{array}{l}\text { No known interhuman } \\
\text { transmission—Standard IP\&C } \\
\text { measures. Aerosol infection in } \\
\text { laboratory setting—full PPE }\end{array}$ & $\begin{array}{l}\text { Jaundice, renal impairment, } \\
\text { encephalopathy, haemorrhage } \\
\text { CFR }=20 \%\end{array}$ \\
\hline $\begin{array}{l}\text { Omsk hemorrhagic fever } \\
\text { virus }\end{array}$ & Omsk HF & Russian federation & Ticks, infected muskrats & $3-14$ & Supportive & $\begin{array}{l}\text { No known interhuman spread } \\
\text { - Standard IP\&C measures. } \\
\text { Aerosol infection in laboratory } \\
\text { setting - full PPE }\end{array}$ & $\begin{array}{l}\text { Biphasic_first phase: fever, myalgia, } \\
\text { headache, diarrhoea, vomiting, } \\
\text { haemorrhage } \\
\text { second phase: fever, encephalitic symptoms } \\
\text { CFR }=0.4-2.5 \%\end{array}$ \\
\hline Kyasanur forest disease virus & $\begin{array}{l}\text { Kyasanur Forest } \\
\text { disease }\end{array}$ & India, Western China & Ticks, infected monkeys & $3-8$ & Supportive & $\begin{array}{l}\text { Suggestion of nosocomial } \\
\text { spread. Consider isolation and } \\
\text { full PPE. High risk of infection } \\
\text { in laboratory setting - full PPE }\end{array}$ & $\begin{array}{l}\text { Biphasic—first phase: fever, myalgia, } \\
\text { headache, haemorrhage, conjunctivitis } \\
\text { second phase-neurological manifestations } \\
\text { CFR }=2-30 \% \text { (recent studies indicate }<4 \% \text { ) }\end{array}$ \\
\hline $\begin{array}{l}\text { Alkhurma hemorrhagic fever } \\
\text { virus (variant of Kyasanur) }\end{array}$ & Alkhurma $\mathrm{HF}$ & Saudi Arabia, Egypt & $\begin{array}{l}\text { Ticks, mosquitoes, infected } \\
\text { animals (sheep, camels), } \\
\text { unpasteurised milk }\end{array}$ & $3-8$ & Supportive & $\begin{array}{l}\text { No known interhuman } \\
\text { transmission—Standard IP\&C } \\
\text { measures. }\end{array}$ & $\begin{array}{l}\text { Fever, headache, myalgia/arthralgia, } \\
\text { vomiting, haemorrhage, encephalitis } \\
\text { CFR=Up to } 25 \%\end{array}$ \\
\hline
\end{tabular}


Table 2 Clinical features of viral haemorrhagic fevers in children

\begin{tabular}{ll}
\hline General/systemic & Gastrointestinal \\
Fever (90\%) & Loss of appetite (73\%) \\
Headache (59\%) & Abdominal pain (47\%) \\
Myalgia (38\%) & Vomiting (62\%) \\
Arthralgia (35\%) & Diarrhoea (60\%) \\
Fatigue/weakness (79\%) & Jaundice (11\%) \\
$\begin{array}{l}\text { Difficulty swallowing (20\%) } \\
\text { Sore throat (16\%) }\end{array}$ & Respiratory \\
Hiccups (7\%) & Difficulty breathing/tachypnoea \\
Rash (6\%) & (20\%) \\
& Cough (31\%) \\
& Chest pain (29\%) \\
Haemorrhagic & \\
Unexplained bleeding (10\%) & Neurological \\
Epistaxis (1.3\%) & Confusion (10\%) \\
Bleeding from gums (2.1\%) & Unresponsive/obtunded (5\%) \\
Bleeding from eyes & Seizures (later stages) \\
Haematemesis (1.4-1.9\%) & \\
$\begin{array}{l}\text { Melaena/haemorrhagic diarrhoea (3.2\%) } \\
\text { Vaginal bleeding (0.7\%) }\end{array}$ & Ocular \\
Haematuria (0.5\%) & Conjunctivitis (22\%) \\
Bleeding from injection site (0.5\%) & Eye pain (6\%) \\
Common haematological/biochemical parameters & \\
Leucopenia & \\
Thrombocytopenia & \\
Transaminitis & \\
Coagulopathy-prolonged PT, APTT and reduced & \\
fibrinogen & \\
\hline $\begin{array}{l}\text { Percentage figures are symptom incidence specifically for children presenting during } \\
\text { the current Ebola virus epidemic in West Africa. }\end{array}$ & \\
APTT, activated partial thromboplastin time; PT, prothrombin time.
\end{tabular}

the virus without being affected by it. Non-human primates also host the virus, but have high mortality rates. ${ }^{3}$ Once the Ebola virus enters human circulation, transmission is maintained through human-to-human infections. ${ }^{3}$

In the current outbreak of EVD in West Africa mortality rates have been particularly high (approximately 80\%) in children under the age of 5 years, with mortality in infants under 1 year of age close to $90 \%$. In contrast children aged 10-15 years have a low mortality rate when compared with all age groups (approximately 50\%). ${ }^{2}$

The incubation period for the virus is from 2 days to 21 days. Detection of Ebola viral RNA by PCR in peripheral blood is likely only in the presence of clinical symptoms, so testing of asymptomatic individuals is not currently indicated, although there have been isolated reports of positive results in presymptomatic individuals, such as that of a pregnant woman. ${ }^{27}$ In the current epidemic the average incubation period in children is shorter than in adults, ranging from approximately 6 days in infants to 9-10 days in children aged $10-15$ years. $^{2}$ Similarly time from symptom onset to death is also quicker in younger children (5-7 days) compared with teenagers and adults (8-9 days), whereas there was little difference between young children, teenagers and adults with regards to time to discharge from hospital as a survivor, which was approximately 14-16 days. There are little data on infants. ${ }^{2}$

Box 2 presents a hypothetical 'worst case scenario', from the perspective of a UK setting. It highlights the generic presentation and theoretical consequences of an EVD case in the UK, even with reasonably prompt recognition of EVD risk factors in the patient. In reality the most common scenarios referred to

\section{Box 1 Key questions for history-taking (from parents)}

1. Which countries have you or your child travelled to in the last 3 weeks and to which regions in these countries?

2. Were you in rural areas with very basic accommodation?

3. Did you work in or did your child attend a healthcare facility in this location?

4. Have you attended any funerals in the last 3 weeks? Did you or your child have any direct contact with the body of the deceased or with someone who had handled the body?

5. Have you or your child come into physical contact with anyone who was unwell in the last 3 weeks?

6. Have you or your child visited any enclosed areas where bats may have lived such as mines or caves?

7. Have you or your child come into contact with any monkeys or other 'bush' animals? Have you or your child prepared or eaten any 'bush meat' such as bat, monkey or forest antelope?

8. Has your child been in an environment where ticks may be present such as in forests or long grass? Have they sustained a tick bite or crushed a tick with their bare hand/foot?

9. Have you or your child visited an abattoir or tannery or been involved in the slaughter of animals?

the UK Imported Fever Service have a low probability (no credible exposure) and test negative; depending on possibility of VHF, full personal protective equipment (PPE) may be recommended pending the results of urgent testing to exclude VHF.

Management of patients with EVD is generally supportive, including symptomatic treatment of fever, pain and vomiting. Profound hypovolaemia can occur from profuse diarrhoea and vomiting. While oral fluids may normally be preferred, in the context of wet symptoms in EVD, intravenous fluids are essential. Remaining ahead of the fluid loss appears key to improved outcomes and is likely to reduce the risk of prerenal failure. ${ }^{28} 29$ Due to the copious diarrhoea, electrolyte abnormalities are common and regular monitoring is essential where available. ${ }^{30}$ A key feature of EVD is its propensity to cause thrombocytopenia, liver enzyme derangement and disseminated intravascular coagulation, all of which may result in profuse bleeding. These blood parameters should be monitored regularly, to expedite timely intervention with platelets, vitamin $\mathrm{K}$ or fresh frozen plasma. It is important to remain vigilant for signs of evolving bacterial sepsis, particularly Gram-negative sepsis from translocation of gut pathogens. ${ }^{31}$ There is no proven treatment for EVD, however outcomes of early trials are anticipated in the near future. WHO advises the use of convalescent plasma in children with EVD on compassionate grounds at a dose of $10 \mathrm{~mL} / \mathrm{kg}$ whole blood or plasma with close monitoring of efficacy, ${ }^{30}$ however data from the convalescent plasma trial will soon be available which may alter this recommendation (see clinicaltrials.gov identifier NCT02333578).

There are unpublished clinical trials into the use of monoclonal antibody products (ZMAPP) and antiviral medications such as favipiravir and TKM-Ebola. Although a dose regimen for favipiravir use in children has been described, ${ }^{32}$ there is no published evidence to support the efficacy of this or any other antiviral for treatment of Ebola in children. Ribavirin does not appear effective in EVD. ${ }^{533}$ Clinical trials of two potential vaccinations are ongoing. 
A
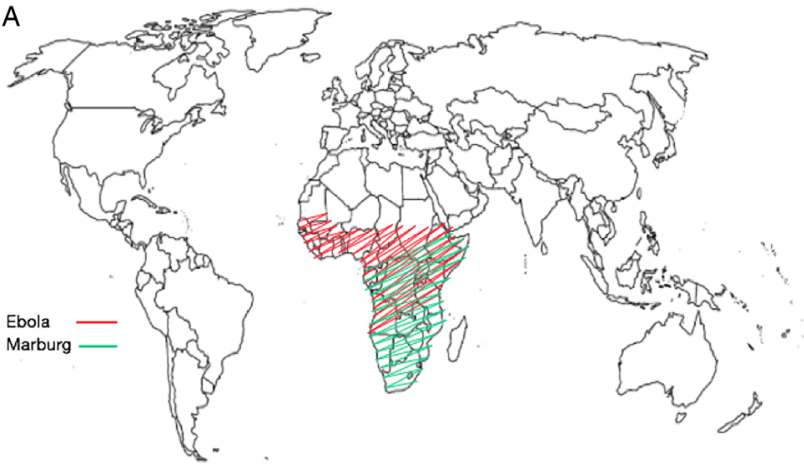
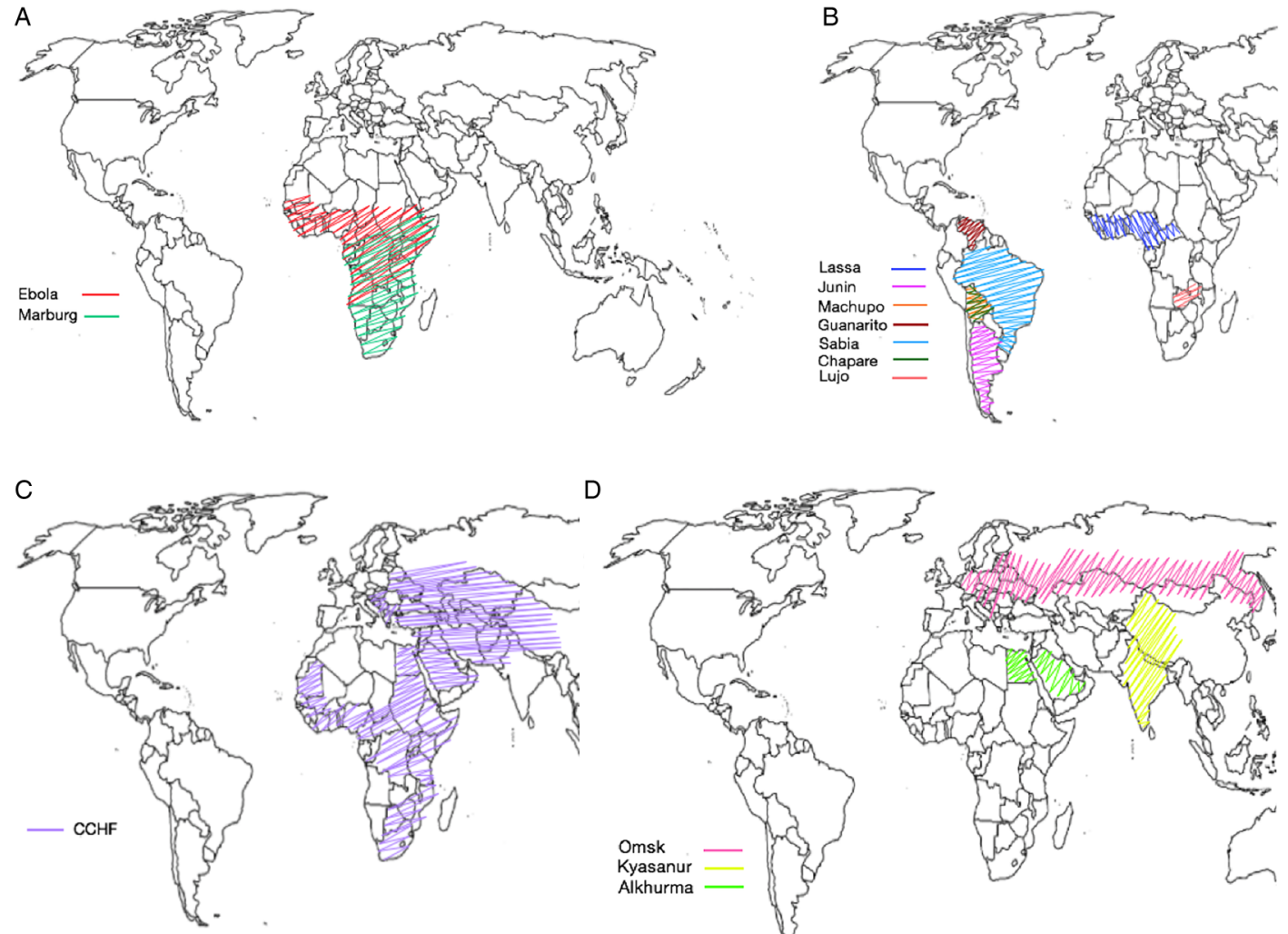

D

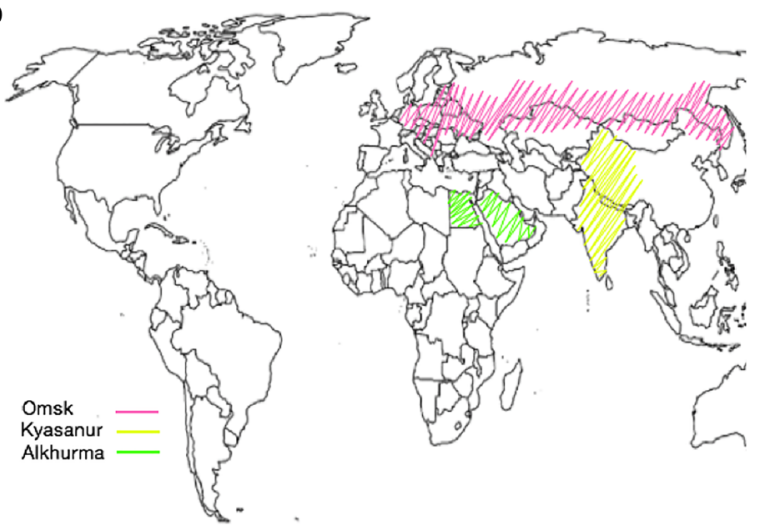

Figure 1 (A) Map of Filoviridae viral haemorrhagic fever (VHF). (B) Map of Arenaviridae viral haemorrhagic fever. (C) Map of Bunyaviridae viral haemorrhagic fever. (D) Map of Flaviviridae viral haemorrhagic fever.

Breast feeding is contraindicated in EVD, as it is a potential mechanism of transmission of virus. The risk of transmission is from infected mother to infant as well as from infected infant to mother. It is therefore recommended that, where appropriate formula milk is available, breast feeding should cease and formula milk be provided. Where mother and infant are infected, breast feeding should continue. ${ }^{34}$ There have been reports of transmission of virus to infants through the breast milk of lactating Ebola survivors (personal communication), but it is unclear how long Ebola virus may persist in breast milk following a woman's survival from the disease. In these circumstances, where testing facilities are available, we suggest breast feeding of an unaffected infant by a mother who has survived EVD should not recommence until two consecutive PCR tests at least $48 \mathrm{~h}$ apart have determined the breast milk to be free of virus.

Neonates are an extremely vulnerable group in the context of EVD. Unborn infants who contract the disease in utero from an infected mother are highly viraemic and often stillborn. The placenta in these cases is highly infectious and the management of pregnant women in labour, or those miscarrying, is extremely high-risk and often complicated by significant haemorrhage. ${ }^{35}$ Assisting with delivery should only be undertaken by those specifically trained in this area. The few infants born alive rarely live beyond a few days, there is only one report of such an infant surviving. This is a recent case born at a treatment facility in Guinea, who received treatment with ZMAPP and an experimental antiviral, GS5734. ${ }^{36}$ Neonates who contract Ebola during the first weeks of life from an infected parent or sibling also have very high mortality rates. In either circumstance, for the best chances of survival, treatment should be started promptly, with due consideration to the use of experimental therapies under compassionate care guidance. Testing should be performed on the basis of exposure, even in the absence of symptoms, to facilitate early intervention. With regards to poor outcomes however, due consideration should be given to the benefits of escalation of care in neonatal EVD, particularly in the case of liveborn infants to a mother infected with EVD prior to delivery.

Most pregnant women with EVD tend to miscarry or deliver their infant in the acute phase of the disease. ${ }^{35}$ There is evidence to suggest that women surviving Ebola with an intact pregnancy pose a significant risk to healthcare workers when they do deliver and that the products of conception and the infant may remain infected. ${ }^{37}$ In this circumstance the mother should be delivered at a facility specifically designed for managing pregnant women infected with EVD and the infant, whether liveborn or stillborn should be assumed to be infected. If liveborn, the infant should be monitored in an high-level isolation unit (HLIU) for a minimum of 21 days and consideration given to early testing and treatment even in the absence of symptoms.

There is some evidence for the spread of Ebola virus from individuals with mild or subclinical EVD. A recent report describes sexual transmission of EVD via semen, from a survivor who had mildly symptomatic EVD 6 months previously. ${ }^{38} \mathrm{~A}$ recent WHO situation report also documents a case of a stillborn infant in Sierra Leone born to a well mother with no known history of infection; the infant tested positive for Ebola virus and serological testing of the mother revealed antibodies to Ebola. ${ }^{37}$ These cases are relevant for the paediatrician in relation to the potential for asymptomatic infection in mothers with spread to their unborn or newborn infants through in utero transmission or possibly through breast milk. Similarly the potential for sexual transmission should be considered in 
adolescents with a history of EVD. It is important that comprehensive information regarding the use of condoms is provided to young men at discharge as well as consideration given to the monitoring of bodily fluids for viral persistence.

There are reports of post-Ebola sequelae, ${ }^{39}$ including critical illness or life-limiting complications, and of viral persistence in semen, intraocular fluid, cerebrospinal fluid (CSF), vaginal secretions and breast milk. ${ }^{40-42}$ There is no clear data as to the proportion of survivors suffering from sequelae or viral persistence in bodily fluid in the most recent epidemic; this crucial research is currently underway. The most common sequelae appear to be eye disease (usually an acute uveitis which can lead to cataracts or blindness), ${ }^{43}$ headache, chronic joint pain, chronic fatigue and sleep disturbance. ${ }^{39}$ There has been one reported case of re-emergence of the virus in CSF resulting in viral meningitis (UK national press). Most of the current reports pertain to adults, however increasingly similar sequelae in children are becoming apparent, particularly eye disease resulting in cataracts (personal communication).

\section{Marburg haemorrhagic fever}

Marburg haemorrhagic fever (MHF) is caused by Marburg marburgvirus. It was first identified in 1967 when a group of cases occurred in Marburg, Germany and simultaneously in Belgrade, former Yugoslavia, linked to imported African green monkeys. Since that time there have been three significant outbreaks of Marburg (Uganda, DRC and Angola), and a handful of isolated cases or small clusters (two to three cases) in Kenya, DRC, Uganda and Zimbabwe/South Africa. ${ }^{44}$ See figure 1 for regions of the world known to be at risk from Marburg virus.

Most cases of MHF appear to be linked to work in or visits to caves or mines. ${ }^{3} 7$ The reservoir is unclear but is widely considered to be fruit bats. ${ }^{7}$ Human infection arises either through contact with bat secretions or other infected wildlife including non-human primates and forest antelope. There is then subsequent human-to-human spread. ${ }^{3}$ The number of paediatric MHF cases has been limited, and there are few relevant publications. $^{25}$

The incubation period for MHF is similar to EVD, ranging from 2 days to 21 days. ${ }^{3}$ Presentations in adults are similar to those of EVD. ${ }^{8} 9$ Management of MHF is supportive and similar principles to the management of EVD apply. There are currently no specific therapies, though therapies being trialled for EVD may be of potential benefit in MHF. Early studies showed no benefit of ribavirin. 5633

\section{ARENAVIRIDAE}

\section{Lassa fever and other Arenaviridae}

The Arenaviridae family incorporates seven RNA viruses known to cause haemorrhagic fever in humans. There is wide geographical distribution throughout South America and Africa, with highest endemicity in West Africa. Arenaviruses are transmitted to humans through aerosolisation of excreta from rodents. Once transmitted to a human host, transmission is maintained through human-to-human and nosocomial interaction, although this appears less common than in EVD and MHF. ${ }^{3}$ The incubation period varies between species (see table 1 ) but overall is considered to be 5-21 days. ${ }^{3}$

Although true incidence data is lacking Lassa fever is estimated to affect approximately 300000 people in West Africa each year with an estimated 5000 deaths. ${ }^{10}$ Lassa may present with similar clinical features to other VHFs (table 2), although in the advanced form can cause significant oedema and pleural effusions. It has less severe haemorrhagic elements when compared with EVD and MHF. ${ }^{10}$ Paediatric Lassa fever is not well described; a paper from 1987 gives mortality rates of $27 \%$ in Liberia, ${ }^{45}$ however this is likely an inflated figure as a significant proportion of milder cases will have been missed in this context. Paediatric Lassa fever may commonly present as a nonspecific febrile illness, but a severe form known as 'swollen baby syndrome' has also been described in Liberia. This is a condition consisting of gross oedema, abdominal distension and bleeding, with a very high mortality rate. ${ }^{3} 4546$ Ribavirin is effective in Lassa fever and if given within the first few days of symptom onset can significantly reduce mortality. ${ }^{47}$ Alongside ribavirin, supportive therapy as described for EVD above is the mainstay of treatment.

Other arenaviruses are listed in table 1 and consist of the South American Arenaviruses and Lujo virus, a recently identified virus in Zambia that caused a small cluster of nosocomial infections. There is limited paediatric data available for these viruses highlighting a significant gap in medical knowledge in this area. Large studies of the efficacy of ribavirin have not been conducted in either adult or paediatric populations, but based on its mechanism of action it is thought to be beneficial in all arenaviral infections. ${ }^{3} 212247$ See figure 1 for regions of the world known to be at risk from the Arenaviridae VHF viruses.

\section{BUNYAVIRIDAE}

Bunyaviridae are vectorborne infections, generally transmitted by arthropods, including ticks and mosquitoes, or through contact with rodents.

\section{Crimean-Congo haemorrhagic fever}

Crimean-Congo haemorrhagic fever virus is an RNA virus in the Bunyaviridae family. It has a widespread geographical distribution causing outbreaks of Crimean-Congo haemorrhagic fever (CCHF) throughout Africa, eastern Europe, the Middle East, central and western Asia (see figure 1 for regions known to be at risk). It has become increasingly common in recent years in Turkey, South-West Russia and Ukraine. ${ }^{48}$ Children are most commonly infected through tick bites, but thereafter there is a risk of nosocomial spread within healthcare settings. It has an incubation period of 1-13 days ${ }^{3}$ and presents in a similar fashion to other VHFs (table 2), although with a higher preponderance for haemorrhagic symptoms. Children who make up approximately $20 \%$ of all cases, present in a similar fashion to adults, but appear to have a milder course of disease with better survival rates $(>90 \%) .^{3}{ }^{11-13}$ Table 1 further identifies some of the more disease-specific clinical features.

Treatment is currently supportive, although there is ongoing discussion on the benefits of the WHO recommendation to use ribavirin. ${ }^{13} 144950$ A case example is found in box 3, highlighting the clinical features of $\mathrm{CCHF}$ and providing a comparison to the clinical case of EVD; further specific details of CCHF are identified in table 1.

\section{FLAVIVIRIDAE}

The Flaviviridae family of RNA viruses includes the Yellow Fever and Dengue viruses, which can present with haemorrhagic symptoms. These will not be discussed as there is no clear demonstration of nosocomial or person-to-person spread, although there have been reports of transmission of Dengue virus through needlestick injuries. ${ }^{19}$ Lesser-known VHF viruses in this family are the Omsk, Kyasanur and Alkhurma haemorrhagic fever viruses, which are thought to spread from bites of infected ticks, although other methods of transmission have been postulated (see table 1). Outbreaks of these diseases have been small, but 


\section{Box 2 Case study_Ebola virus disease (EVD)}

- A 4-year-old African girl presents with her mother to the emergency department of a children's hospital with 2 days of fever, having returned from visiting family in the Democratic Republic of Congo. Seven days before, they attended a funeral of a family friend who died unexpectedly. The mother denies any involvement in the burial preparation of the body.

- The child developed diarrhoea and vomiting approximately $24 \mathrm{~h}$ ago, and is increasingly weak and floppy, complaining of abdominal pain and headache. On examination she appears weak and lethargic, with tachycardia, sunken eyes and reduced skin turgor. Abdominal examination reveals generalised tenderness. Blood testing detects a potassium of $3.3 \mathrm{mmol} / \mathrm{L}$ and a urea of $7.5 \mathrm{mmol} / \mathrm{L}$. She has a normal full blood count and $C$ reactive protein. A malaria film is negative.

- She is admitted to a cubicle where basic barrier nursing measures are applied. She deteriorates overnight, remaining pyrexial up to $40.5^{\circ} \mathrm{C}$. The following morning her diarrhoea is noted to have occasional streaks of fresh red blood. Repeat blood tests reveal a platelet count of $80 \times 10^{9} / \mathrm{L}$, WBC $18 \times 10^{9} / \mathrm{L}$, potassium $3.1 \mathrm{mmol} / \mathrm{L}$, urea $8.5 \mathrm{mmol} / \mathrm{L}$ creatine $105 \mu \mathrm{mol} / \mathrm{L}$, ALT $450 \mathrm{IU}$ and CRP $30 \mathrm{mg} / \mathrm{L}$. Because of the travel history, and presence of bleeding with low platelets, concerns are raised over the possibility of a viral haemorrhagic fever and advice is sought from the regional paediatric infectious disease team, and the national Rare and Imported Fever Service. Ebola virus is confirmed by PCR at the national reference laboratory.

- She is transferred to a high level isolation unit (HLIU) but deteriorates, developing multiorgan failure. On day 6 she arrests and resuscitation attempts are unsuccessful. Her family is monitored for signs of the disease, and her mother and 10 year-old brother develop a fever and test positive for EVD.

- The clinical team are monitored for 21 days following exposure. On day 11, a nurse who cared for her prior to her HLIU admission, and without full personal protective equipment, develops a fever and tests positive for EVD.

nosocomial spread has been suggested although not demonstrated in Kyasanur forest disease (KFD). ${ }^{51}$ Laboratory transmission has occurred in Omsk HF and KFD where transmission through the handling of infected monkey carcasses has also occurred. ${ }^{152351}$ There are few documented paediatric cases of Alkhurma and KFD, but approximately a third of cases of Omsk HF occur in the paediatric population, where there is a biphasic disease pattern with a high incidence (41\%) of meningitic/encephalitic symptoms in the second phase. ${ }^{15}{ }^{16} 52$ Treatment is supportive with no evidence for ribavirin. ${ }^{15} 16$ See figure 1 for regions of the world known to be at risk from Flaviviridae VHF and table 1 for clinical details of each disease.

\section{SAFE MANAGEMENT OF PAEDIATRIC PATIENTS WITH VHF}

The fundamental principle of initial management is an early and careful risk assessment, made in conjunction with regional and national paediatric infectious diseases and public health teams, together with proportionate patient isolation and use of PPE to reduce risks of onward transmission, pending the outcome of VHF testing. The approach, including the challenges of isolating
Box 3 Case study-Crimean-Congo haemorrhagic fever (CCHF)

- A 7-year-old boy returned from a holiday in Turkey 7 days ago. He presents to the children's assessment unit at a district general hospital with a fever of $39^{\circ} \mathrm{C}$ for $24 \mathrm{~h}$, muscle pain and headache. He is vomiting, with streaks of blood. His mother reports that he played in fields and woods while in Turkey.

- Clinical assessment reveals an acutely unwell, pale child with tachycardia. He develops melaena and epistaxis. Blood results reveal a leucopenia of $1.9 \times 10^{9} / \mathrm{LWBC}$, platelets of $6 \times 10^{9} / \mathrm{L}$, ALT of $300 \mathrm{IU}$, prothrombin time of $17 \mathrm{~s}$ and activated partial thromboplastin time of $78 \mathrm{~s}$. He is treated with fresh frozen plasma, a platelet transfusion and vitamin $K$, following which his bleeding resolves. An infection screen at this stage reveals a positive PCR result for CCHF virus. He is transferred to a high-level isolation unit.

- Over the course of the next $48 \mathrm{~h}$ he improves gradually. Repeat blood tests on day 7 are negative for CCHF on PCR. He makes a full recovery. The rest of his family remain well. The medical and nursing staff at the district general hospital are monitored for 14 days but none shows signs of developing CCHF.

and safely transporting the child, is discussed in more detail by Herberg JA et al. ${ }^{53}$

Patients with confirmed hazard group 4 VHF must be cared for in units with appropriate isolation facilities, by a designated, trained team. The features of such a unit, the appropriate PPE for healthcare workers and the management of such patients are described in the document 'Management of Hazard Group 4 viral haemorrhagic fevers and similar human infectious diseases of high consequence' produced by the ACDP. ${ }^{20}$

Provision of intensive care including ventilation and haemofiltration to patients with VHF may increase the risks of onward transmission to healthcare workers, but several returning healthcare workers with EVD have made a good recovery after receiving intensive care. ${ }^{54-56}$ There are no reports of children with VHF receiving intensive care and weighing of risks and benefits must be made on a case-by-case basis. Current UK Department of Health guidance suggests intensive care procedures should only be undertaken where there is clear benefit to the patient, at an HLIU where protection of healthcare workers is maximised..$^{53}$

\section{SUMMARY}

VHFs include varied, unrelated viruses with the potential to cause haemorrhagic symptoms as part of the disease process. Not all patients with VHF will manifest haemorrhagic symptoms and early presentations of disease may be very nonspecific. Paediatric presentations may be even more generic when compared with presentations of other infectious diseases and are currently poorly described in the literature, indicating a significant need for informed research in this area. The importance of taking a detailed, specific history to identify the possibility of such a pathogen to the attending clinician must be emphasised due to the high risk of nosocomial spread. Early prompt treatment by a specialist team in an HLIU improves patient outcome and protects healthcare workers. 
Acknowledgements The authors thank Dr Andrew Simpson for his advice and review of the paper.

Funding NEM receives funding from the Wellcome Trust Institutional Strategic Support Fund and the Institute of Global Health Innovation at Imperial College London; JAH is supported by NIHR Imperial College BRC and EU fp7 funding.

Competing interests None declared.

Provenance and peer review Commissioned; externally peer reviewed.

\section{REFERENCES}

1 WHO Ebola Response TeamAylward B, Barboza P, et al. Ebola virus disease in West Africa - the first 9 months of the Epidemic and Forward Projections. N Eng/ J Med 2014;371:1481-95

2 WHO Ebola Response TeamAgua-Agum J, Ariyarajah A, et al. Ebola virus disease among children in West Africa. N Engl J Med 2015;372:1274-7.

3 Guerrant RL, Walker DH, Weller PF. Tropical Infectious Diseases: Principles, Pathogens and Practice (Expert Consult-Online and Print), 3e. 3rd edn. Saunders, 2011.

4 Cherry J, Demmler-Harrison GJ, Kaplan SL, et al. Feigin and Cherry's textbook of pediatric infectious diseases: expert consult. Online and Print, 2-Volume Set, 7e. 7th edn. Saunders, 2013.

5 Bausch DG, Sprecher AG, Jeffs B, et al. Treatment of Marburg and Ebola hemorrhagic fevers: a strategy for testing new drugs and vaccines under outbreak conditions. Antiviral Res 2008;78:150-61.

6 Huggins JW. Prospects for treatment of viral hemorrhagic fevers with ribavirin, a broad-spectrum antiviral drug. Rev Infect Dis 1989;11(Suppl 4):S750-61.

7 Rougeron V, Feldmann H, Grard G, et al. Ebola and Marburg haemorrhagic fever. J Clin Virol 2015;64:111-19.

8 van Paassen J, Bauer MP, Arbous MS, et al. Acute liver failure, multiorgan failure cerebral oedema, and activation of proangiogenic and antiangiogenic factors in a case of Marburg haemorrhagic fever. Lancet Infect Dis 2012;12:635-42.

9 Roddy P, Thomas SL, Jeffs B, et al. Factors associated with Marburg hemorrhagic fever: analysis of patient data from Uige, Angola. J Infect Dis 2010;201:1909-18.

10 Khan SH, Goba A, Chu M, et al. New opportunities for field research on the pathogenesis and treatment of Lassa fever. Antiviral Res 2008;78:103-15.

11 Kızılgun M, Ozkaya-Parlakay A, Tezer $\mathrm{H}$, et al. Evaluation of Crimean-Congo hemorrhagic fever virus infection in children. Vector Borne Zoonotic Dis 2013;13:804-6.

12 Dilber E, Cakir M, Acar EA, et al. Crimean-Congo haemorrhagic fever among children in north-eastern Turkey. Ann Trop Paediatr 2009:29:23-8.

13 Ozkurt Z, Kiki I, Erol S, et al. Crimean-Congo hemorrhagic fever in Eastern Turkey: clinical features, risk factors and efficacy of ribavirin therapy. J Infect 2006;52:207-15.

14 Ascioglu $\mathrm{S}$, Leblebicioglu $\mathrm{H}$, Vahaboglu $\mathrm{H}$, et al. Ribavirin for patients with Crimean-Congo haemorrhagic fever: a systematic review and meta-analysis. J Antimicrob Chemother 2011:66:1215-22.

15 Růžek D, Yakimenko VV, Karan LS, et al. Omsk haemorrhagic fever. Lancet 2010;376:2104-13.

16 Lani R, Moghaddam E, Haghani A, et al. Tick-borne viruses: a review from the perspective of therapeutic approaches. Ticks Tick Borne Dis 2014:5:457-65.

17 Carletti F, Castilletti C, Di Caro A, et al. Alkhurma hemorrhagic fever in travelers returning from Egypt, 2010. Emerging Infect Dis 2010;16:1979-82.

18 Mehla R, Kumar SRP, Yadav $\mathrm{P}$, et al. Recent ancestry of Kyasanur Forest disease virus. Emerging Infect Dis 2009;15:1431-7.

19 Morgan C, Paraskevopoulou S-M, Ashley EA, et al. Nosocomial transmission of dengue fever via needlestick. An occupational risk. Travel Med Infect Dis 2015;13:271-3.

20 Advisory Committee on Dangerous Pathogens. Management of Hazard Group 4 viral haemorrhagic fevers and similar human infectious diseases of high consequence. 2014. https://wwwgovuk/government/publications/ viral-haemorrhagic-fever-algorithm-and-guidance-on-management-of-patients

21 Sewlall NH, Richards G, Duse A, et al. Clinical features and patient management of Lujo hemorrhagic fever. PLoS Negl Trop Dis 2014;8:e3233.

22 Delgado S, Erickson BR, Agudo R, et al. Chapare virus, a newly discovered arenavirus isolated from a fatal hemorrhagic fever case in Bolivia. PLOS Pathog 2008:4:e1000047.

23 Holbrook MR. Kyasanur forest disease. Antiviral Res 2012;96:353-62.

24 Li DX. Severe fever with thrombocytopenia syndrome: a newly discovered emerging infectious disease. Clin Microbiol Infect 2015;21:614-20.

25 Borchert M, Muyembe-Tamfum JJ, Colebunders R, et al. Short communication: a cluster of Marburg virus disease involving an infant. Trop Med Int Health 2002;7:902-6

26 World Health Organisation. Ebola Situation Report-2nd December 2015. 2015. http://apps.who.int/ebola/current-situation/ebola-situation-report-2-december-2015
27 Akerlund E, Prescott J, Tampellini L. Shedding of Ebola Virus in an Asymptomatic Pregnant Woman. N Engl J Med 2015;372:2467-9.

28 Hunt L, Gupta-Wright A, Simms V, et al. Clinical presentation, biochemical, and haematological parameters and their association with outcome in patients with Ebola virus disease: an observational cohort study. Lancet Infect Dis 2015;15:1292-9.

29 Lyon GM, Mehta AK, Varkey JB, et al. Clinical care of two patients with Ebola virus disease in the United States. N Engl J Med 2014;371:2402-9.

30 Eriksson CO, Uyeki TM, Christian MD, et al. Care of the child with Ebola virus disease. Pediatr Crit Care Med 2015;16:97-103.

31 Kreuels $B$, Wichmann $D$, Emmerich $P$, et al. A case of severe Ebola virus infection complicated by gram-negative septicemia. N Engl J Med 2014;371:2394-401.

32 Bouazza N, Treluyer J-M, Foissac F, et al. Favipiravir for children with Ebola. Lancet 2015;385:603-4.

33 Bronze MS, Greenfield RA. Therapeutic options for diseases due to potential vira agents of bioterrorism. Curr Opin Investig Drugs 2003;4:172-8

34 World Health Organisation, United Nations Children's Fund, Centers for Disease Control. Infant feeding and Ebola_further clarification on guidance. 2014. http:/l www.ennonline.net/infantfeedinginthecontextofebola2014

35 Jamieson DJ, Uyeki TM, Callaghan WM, et al. What obstetrician-gynecologists should know about Ebola: a perspective from the Centers for Disease Control and Prevention. Obstet Gynecol 2014;124:1005-10.

36 Farge E. Guinea's last Ebola case, a baby girl, leaves hospital. 2015. http://in reuters.com/article/us-health-ebola-guinea-idINKBNOTHOPB20151128

37 World Health Organisation. Ebola situation report-June 3rd 2015. 2015. http:// appswhoint/ebola/en/current-situation/ebola-situation-report-3-june-2015

38 Mate SE, Kugelman JR, Nyenswah TG, et al. Molecular evidence of sexual transmission of Ebola virus. N Engl J Med 2015:373:2448-54.

39 Clark DV, Kibuuka H, Millard M, et al. Long-term sequelae after Ebola virus disease in Bundibugyo, Uganda: a retrospective cohort study. Lancet Infect Dis 2015:15:905-12.

40 Deen GF, Knust B, Broutet N, et al. Ebola RNA Persistence in Semen of Ebola Virus Disease Survivors-Preliminary Report. N Engl J Med 2015 Published Online First: 14 October 2015

41 Varkey JB, Shantha JG, Crozier I, et al. Persistence of Ebola virus in ocular fluid during convalescence. N Engl J Med 2015;372:2423-7.

42 Bausch DG, Towner JS, Dowell SF, et al. Assessment of the risk of Ebola virus transmission from bodily fluids and fomites. J Infect Dis 2007;196(Suppl 2): S142-7.

43 Kibadi K, Mupapa K, Kuvula K, et al. Late ophthalmologic manifestations in survivors of the 1995 Ebola virus epidemic in Kikwit, Democratic Republic of the Congo. J Infect Dis 1999;179(Suppl 1):S13-14.

44 World Health Organisation. Marburg haemorrhagic fever. http://www.who.int.http:// www.who.int/csr/don/archive/disease/marburg virus disease/en/ (accessed 8 Jul 2015)

45 Monson MH, Cole AK, Frame JD, et al. Pediatric Lassa fever: a review of 33 Liberian cases. Am J Trop Med Hyg 1987;36:408-15.

46 Webb PA, McCormick JB, King IJ, et al. Lassa fever in children in Sierra Leone, West Africa. Trans R Soc Trop Med Hyg 1986;80:577-82.

47 Kerber R, Reindl S, Romanowski V, et al. Research efforts to control highly pathogenic arenaviruses: a summary of the progress and gaps. J Clin Virol 2015;64:120-7.

48 Maltezou HC, Andonova L, Andraghetti R, et al. Crimean-Congo hemorrhagic fever in Europe: current situation calls for preparedness. Euro Surveill 2010;15:19504.

49 Elaldi N, Bodur $\mathrm{H}$, Ascioglu S, et al. Efficacy of oral ribavirin treatment in Crimean-Congo haemorrhagic fever: a quasi-experimental study from Turkey. J Infect 2009:58:238-44

50 Ergonul O. DEBATE (see Elaldi $\mathrm{N}$ et al., Efficacy of oral ribavirin treatment in Crimean-Congo haemorrhagic fever: a quasi-experimental study from Turkey. Journal of Infection 2009;58:238-244): Biases and misinterpretation in the assessment of the efficacy of oral ribavirin in the treatment of Crimean-Congo hemorrhagic fever. Infect 2009:59:284-6; author reply 286-9.

51 Mourya DT, Yadav PD, Patil DY. Highly infectious tick-borne viral diseases: Kyasanur forest disease and Crimean- Congo haemorrhagic fever in India. WHO South-East Asia Journal of Public Health 2014;3:8-21.

52 Kasabi GS, Murhekar MV, Yadav PD, et al. Kyasanur Forest disease, India, 2011-2012. Emerging Infect Dis 2013;19:278-81.

53 Herberg JA, Emonts $M$, Jacobs $M$, et al. UK preparedness for children with Ebola infection. Arch Dis Child 2015;100:421-3.

54 Wolf $\mathrm{T}$, Kann G, Becker $\mathrm{S}$, et al. Severe Ebola virus disease with vascular leakage and multiorgan failure: treatment of a patient in intensive care. Lancet 2015;385:1428-35

55 Brown C, Kreuels B, Baker $\mathrm{P}$, et al. Ebola and provision of critical care. Lancet 2015:385:1392

56 Murthy S, Ebola Clinical Care authors group. Ebola and provision of critical care. Lancet 2015;385:1392-3. 